\title{
Selenium content in meals consumed for lunch by Sri Lankans and the effect of cooking on selenium content
}

\author{
K.M.S.D. Kiridena, D. S. M. De Silva* and S. Wimalasena \\ Department of Chemistry, University of Kelaniya, Kelaniya, Sri Lanka.
}

Received:22/05/2017; Accepted:27/09/2017

\begin{abstract}
The selenium (Se) content in meals consumed by Sri Lankans for lunch, composed of fixed and random menus, was determined using Hydride Generation Atomic Absorption Spectrometer. The samples were obtained from five districts in Sri Lanka. The Se content $(\mu \mathrm{g} / \mathrm{kg})$ in meals of fixed and random menus was in the range of 48-70 and 53-60 respectively. These values are comparable to the daily requirement of Se $(55 \mu \mathrm{g} / \mathrm{kg})$ prescribed by the World Health Organization and Food and Agriculture Organization of the United Nations. There is no significant difference in Se content in meals consumed by people in the districts of Kandy, Gampaha, Kurunegala, Rathnapura, and Colombo, as well as among individual households in each district. The effects of different cooking methods on the Se content indicate that the level of Se $(\mu \mathrm{g} / \mathrm{kg})$ in fried chicken $(30.45-52.49)$ is less than that in a chicken curry (61.38 - 84.25). The percentage loss of Se during cooking for chicken, dahl (Lens culinaris) and Gotukola (Centella asiatica) were $89.6 \%, 84.1 \%$, and $79.9 \%$ respectively. The present study revealed that Se content in Sri Lankan menus provides the required Se for people. However, the different methods of cooking indicate that there is a loss of Se during cooking.
\end{abstract}

Keywords: Selenium, Composite meal, Daily intake.

\section{INTRODUCTION}

Selenium (Se) is a trace element that is important in human nutrition. This is due to the presence of Se dependent enzymes (selenoenzymes) that help to reduce oxidative stress, DNA damage, coronary heart disease and cancer (Briggs, 1999; Patric, 2004). Deiodinases (Type I, II, III) that contains Se plays an important role in thyroid hormone metabolism, hence deficiency of Se results in defects in the thyroid metabolism (Nerve, 1996).

Suffiecient Se contents in food have been reported in other countries, but not many reports are available from Sri Lanka except a study done on raw rice (Mahagama, 2009), vegetables and cereals (Bandara, 2012; Buwaneka, 2014; Prasanna, 2014). According to literature, Se levels in organ meats and seafood can range from $0.4-1.5 \mu \mathrm{g} \mathrm{Se} / \mathrm{g}$, muscle meats $0.1-0.4 \mu \mathrm{g}$ $\mathrm{Se} / \mathrm{g}$, and dairy products contain $<0.1-0.3 \mu \mathrm{g}$ Se/g (Sunde et al., 2006). Elsewhere, the effects of cooking on Se content has been reported (Higgs et al., 1972; Bratakos et al., 1987). The studies showed that there is a loss of Se during cooking, where part of it can be absorbed by the cooking utensils while some escape in the gaseous phase. However, in spite of substantial losses while cooking fish and meat, their contribution as sources of $\mathrm{Se}$ is significant as they contain high levels of Se. Raw vegetables are regarded as poor Se sources for humans (typically $<0.1 \mu \mathrm{g} \mathrm{Se} / \mathrm{g}$ ), with the exception of Brazil nuts and mushrooms which contain high levels of Se. Se content in cereals and grains range from $<0.1$ to $>0.8 \mu \mathrm{g} \mathrm{Se} / \mathrm{g}$ (Sunde et al., 2006). Thus, cooking further lowers the Se content in these types of food. While the principal source of Se for most individuals is the daily intake of food and drinking water, these sources ultimately depend on the soil type, climatic conditions in a given geographical area and also the ability of plants to accumulate Se (Dumont et al., 2006).

Cereals and their products are the major source of dietary Se for Greeks but while cooking 5-30\% Se can get lost. However, wheat grain and flour do not lose Se when subjected to various other thermal processes such as frying, grilling, boiling and canning (Bratakos et al.,1987).

The present study reports the effect of cooking on Se content in three locally consumed accompaniments to rice (chicken curry, dahl curry and Centella asiatica fried salad with 
coconut) and that of a composite meal consumed for lunch by Sri Lankans.

\section{MATERIALS AND METHODS}

\section{Reagents}

69\% Nitric acid (concentrated) (Analytical grade, Sigma - Aldrich), 60\% hydrogen peroxide solution (BDH), 37\% hydrochloric acid (concentrated) (Analytical grade, Fluka), 98\% sodium borohydride (Sd Fine-CHEM), 99\% sodium hydroxide (Sigma-Aldrich), Selenium AAS standard (Reagecon).

\section{Instrument}

Hydride Generation Atomic Absorbance Spectrometer (Analytikjena - NOVAA 400P).

\section{Sampling}

Five samples of meals of fixed (rice, dahl, chicken, C. asiatica salad) and random lunch menus from Kandy, Gampaha, Rathnapura, Kurunegala and Colombo districts (sampled during the periods of April 2014 to October 2014 and June 2015 to August 2015) were analyzed in triplicates. Fried chicken and chicken curry prepared in five households from Kandy and Colombo districts were collected to analyze the effect of method of cooking on Se content.
Loss of Se on cooking was determined for curries prepared from chicken, dahl and C.asiatica prepared in households from the above two districts.

\section{Preparation of samples}

Se contents were determined in six samples that were sun dried for 6-12 hours and oven dried at $80^{\circ} \mathrm{C}$ for 4 hours. Accurately weighed sun dried, powdered samples $(2.500 \mathrm{~g})$ were digested with concentrated nitric acid $(30.00 \mathrm{~mL})$ at $95 \pm 5^{\circ} \mathrm{C}$ for 2 hours, followed by $60 \%$ hydrogen peroxide $(6.00 \mathrm{~mL})$. Addition of hydrogen peroxide was continued with warming until effervescence ceased. The extract was concentrated to $20.0 \mathrm{~mL}$ and cooled to room temperature and filtered using Whatmann No.1 filter paper. The solution was heated to $70 \pm 5^{\circ} \mathrm{C}$ for 30 min with concentrated hydrochloric acid $(4.10 \mathrm{~mL})$, cooled to room temperature and made up to $50.0 \mathrm{~mL}$ with de-ionized water in a volumetric flask. Blank samples were prepared in the same manner but without the powdered food samples.

Se content in digested samples and the standards (AAS standard - Reagecon) were analyzed using Hydride Generation Atomic Absorption Spectrophotometer after digesting the samples with $\mathrm{NaBH}_{4}(0.5900 \mathrm{~g})$ in $0.15 \% \mathrm{NaOH}$ and $3 \% \mathrm{HCl}$.

\section{RESULTS AND DISCUSSION}

\section{Effect of drying method on selenium content}

Table 1: Comparison of Se contents in sun-dried and oven-dried samples.

\begin{tabular}{|c|c|c|c|}
\hline \multirow[b]{2}{*}{ District } & \multirow[b]{2}{*}{ Household } & \multicolumn{2}{|c|}{ Mean Se content $(\mu \mathrm{g} / \mathrm{kg})^{*}$} \\
\hline & & $\begin{array}{l}\text { Sun Drying } \\
(6-12 \mathrm{hrs})\end{array}$ & $\begin{array}{l}\text { Oven Drying } \\
\left(\sim 80^{\circ} \mathrm{C}-4 \mathrm{hrs}\right)\end{array}$ \\
\hline \multirow[t]{3}{*}{ Kandy } & 1 & $66.93 \pm 2.50$ & $66.56 \pm 1.30$ \\
\hline & 2 & $43.15 \pm 8.90$ & $42.74 \pm 0.81$ \\
\hline & 3 & $43.54 \pm 0.13$ & $43.17 \pm 2.27$ \\
\hline \multirow[t]{3}{*}{ Kurunegala } & 1 & $47.37 \pm 8.20$ & $46.29 \pm 2.88$ \\
\hline & 2 & $70.95 \pm 7.89$ & $71.38 \pm 1.80$ \\
\hline & 3 & $59.04 \pm 9.81$ & $59.08 \pm 0.48$ \\
\hline
\end{tabular}

*Mean \pm Standard deviation of determination carried out in triplicates.

Se contents measured in differently dried food samples were similar (Table 1), hence sun drying method was selected as the preferred method of drying for the meal samples. 


\section{Selenium contents in random menus}

Table 2: Se contents in meals (random menu) from different households in each district. Significant differences are highlighted using different lowercase letters. Means were compared between districts.

\begin{tabular}{lccccc}
\hline \multirow{2}{*}{ Household } & \multicolumn{5}{c}{ Se content $(\boldsymbol{\mu g} / \mathbf{k g})^{*}$} \\
\cline { 2 - 5 } & Kandy & Gampaha & Kurunegala & Rathnapura & Colombo \\
\hline 1 & $57.93( \pm 17.39)^{\mathrm{a}}$ & $57.87( \pm 07.98)^{\mathrm{a}}$ & $59.82( \pm 10.93)^{\mathrm{a}}$ & $55.19( \pm 18.32)^{\mathrm{a}}$ & $63.75( \pm 17.02)^{\mathrm{a}}$ \\
2 & $61.52( \pm 13.38)^{\mathrm{a}}$ & $45.06( \pm 18.87)^{\mathrm{a}}$ & $50.96( \pm 14.78)^{\mathrm{a}}$ & $48.65( \pm 19.35)^{\mathrm{a}}$ & $57.49( \pm 15.07)^{\mathrm{a}}$ \\
3 & $48.15( \pm 22.04)^{\mathrm{a}}$ & $58.14( \pm 14.87)^{\mathrm{a}}$ & $64.13( \pm 19.88)^{\mathrm{a}}$ & $64.52( \pm 25.20)^{\mathrm{a}}$ & $56.73( \pm 21.22)^{\mathrm{a}}$ \\
\hline Mean & $55.87( \pm 6.92)^{\mathrm{a}}$ & $53.69( \pm 7.47)^{\mathrm{a}}$ & $58.30( \pm 6.71)^{\mathrm{a}}$ & $56.12( \pm 7.98)^{\mathrm{a}}$ & $59.32( \pm 3.85)^{\mathrm{a}}$
\end{tabular}

*Mean \pm Standard deviation of determination carried out in triplicates.

\section{Selenium content in fixed menus}

Table 3: Se contents in meals (fixed menu) from different households in each district. Significant differences are highlighted using different lowercase letters. Means were compared between districts.

\begin{tabular}{llllll}
\hline \multirow{2}{*}{ Household } & \multicolumn{5}{c}{ Se content $(\boldsymbol{\mu g} / \mathbf{k g})^{*}$} \\
\cline { 2 - 5 } & Kandy & Gampaha & Kurunegala & Rathnapura & Colombo \\
\hline 1 & $63.40( \pm 02.30)^{\mathrm{a}}$ & $62.19( \pm 7.97)^{\mathrm{a}}$ & $80.42( \pm 18.80)^{\mathrm{a}}$ & $58.46( \pm 7.25)^{\mathrm{a}}$ & $59.55( \pm 3.48)^{\mathrm{a}}$ \\
2 & $68.75( \pm 19.69)^{\mathrm{a}}$ & $69.41( \pm 14.62)^{\mathrm{a}}$ & $66.98( \pm 23.85)^{\mathrm{a}}$ & $32.45( \pm 14.77)^{\mathrm{a}}$ & $40.13( \pm 16.80)^{\mathrm{a}}$ \\
3 & $47.70( \pm 14.34)^{\mathrm{a}}$ & $78.31( \pm 18.36)^{\mathrm{a}}$ & $64.08( \pm 7.78)^{\mathrm{a}}$ & $61.73( \pm 7.40)^{\mathrm{a}}$ & $45.25( \pm 28.86)^{\mathrm{a}}$ \\
\hline Mean & $59.95( \pm 10.94)^{\mathrm{a}}$ & $69.97( \pm 8.07)^{\mathrm{a}}$ & $70.49( \pm 8.72)^{\mathrm{a}}$ & $50.88( \pm 16.04)^{\mathrm{a}}$ & $48.31( \pm 10.06)^{\mathrm{a}}$ \\
\hline *Mean \pm Standard deviation of determination carried out in triplicates. & & \\
\hline
\end{tabular}

Significant difference was not observed in the Se levels in meals ( random menu and fixed menu) consumed in each district (along the columns), though the standard deviations varied between \pm 7 to $\pm 26 \mu \mathrm{g} / \mathrm{kg}$ and \pm 2 to $\pm 29 \pm$, respectively (Tables 2 and 3). In random menu samples, higher Se concentrations were recorded as the meals are rich in protein-containing food items such as meat, fish, legumes etc. The present study revealed that mean Se content $(\mu \mathrm{g} / \mathrm{kg})$ in meals (fixed menu and random menu) consumed by people in the five selected districts in Sri Lanka were 56.67 and 59.92 respectively. This value is comparable to the daily requirement of $55 \mu \mathrm{g} /$ day as stated by the Food and Nutrition Board, Institute of Medicine, USA.

\section{Effect of cooking on selenium}

Se contents in chicken curry were greater than that in fried chicken (Table 4). This may be due to higher temperature used in frying compared to that used in preparing a chicken curry resulting volatilization losses of Se. The reason for the differences in the level of Se between the two districts could be due to different factors involved in cooking such as temperature, duration of cooking and the type and diet of the chicken. 
Table 4: Effect of method of cooking on Se content in chicken in households in Kandy and Colombo districts

\begin{tabular}{lcc}
\hline \multirow{2}{*}{ Type of curry } & \multicolumn{2}{c}{ Se content $(\boldsymbol{\mu g} / \mathbf{k g}) *$} \\
\cline { 2 - 3 } & \multicolumn{1}{c}{ Kandy } & Colombo \\
\hline Chicken-curry & $84.25 \pm 1.86$ & $61.38 \pm 0.56$ \\
Chicken- fried & $30.45 \pm 0.62$ & $52.49 \pm 1.51$ \\
\hline *Mean \pm Standard deviation of determination carried out in triplicates.
\end{tabular}

Table 5: Se content in different curries in households in Kandy and Colombo districts.

\begin{tabular}{llc}
\hline \multirow{2}{*}{ Type of curry } & \multicolumn{2}{c}{ Se content $(\boldsymbol{\mu g} / \mathbf{k g}) *$} \\
\cline { 2 - 3 } & Kandy $(\boldsymbol{\mu g} / \mathbf{k g})$ & Colombo $(\boldsymbol{\mu g} / \mathbf{k g})$ \\
\hline Chicken - curry & $84.25 \pm 1.86$ & $61.38 \pm 0.56$ \\
Dahl - curry & $51.41 \pm 1.50$ & $67.87 \pm 0.55$ \\
Cooked Salad & $47.54 \pm 1.47$ & $78.72 \pm 1.07$ \\
\hline *Mean \pm Standard deviation of determination carried out in triplicates.
\end{tabular}

Table 6: Percentage loss of Se during cooking.

\begin{tabular}{lccc}
\hline \multirow{2}{*}{ Type of curry } & \multicolumn{3}{c}{ Se content $(\boldsymbol{\mu g} / \mathbf{k g}) *$} \\
\cline { 2 - 4 } & Cooked $(\boldsymbol{\mu g} / \mathbf{k g})$ & Raw $(\boldsymbol{\mu g} / \mathbf{k g})$ & Loss of Se $(\%)$ \\
\hline Chicken & $72.81 \pm 2.55$ & $702.39 \pm 9.11$ & $89.63 \pm 15.59$ \\
Dahl & $45.04 \pm 8.38$ & $282.40 \pm 10.03$ & $84.05 \pm 8.94$ \\
Cooked Salad & $63.13 \pm 1.20$ & $315.17 \pm 7.57$ & $79.97 \pm 6.02$ \\
\hline
\end{tabular}

*Mean \pm Standard deviation of determination carried out in triplicates.

A significant difference was observed in Se content with the type of food (Table 5). The cause for these differences could be due to different factors involved in cooking such as temperature, duration of cooking and the nature of the food type.

\section{Percentage loss of selenium on cooking}

The results showed a considerable loss of Se during cooking processes of all food items tested (Table 6).

\section{CONCLUSIONS}

The present study revealed that the intake of Se (per meal) by Sri Lankans is in the range $48-70$ $\mu \mathrm{g} / \mathrm{kg}$. No significant differences were observed in Se contents in meals among the selected districts as well as among individual households. Se content in cooked food varied possibly depending on the method of cooking and the type of food. Different cooking methods lead to the loss of Se. However, the cooked meals contain considerable amount of $\mathrm{Se}$ in the diet to be available as a micronutrient.

\section{ACKNOWLEDGMENT}

We are grateful for the financial assistance given by National Science Foundation, Sri Lanka.

(Grant RG/2010/AG/03). 


\section{REFERENCES}

Bandara, S. (2012). Selenium in vegetables consumed by Sri Lankans, B.Sc. Special Degree Dissertation. University of Kelaniya, Sri Lanka.

Bratakos, M. S., Zafiropoulos, T. F., Siskos, P. A. and Ioannou, P. V. (1987). Selenium in foods produced and consumed in Greece. Journal Food Science 52: 817-822.

Briggs, S. (1999). Selenium: Antioxidant and Cancer: A review of the literature. Alternative Medicine Review 3:239-253.

Buwaneka, P.A. (2014). Selenium content in cereals and legume seeds grown in Sri Lanka, Special Degree Dissertation. University of Kelaniya, Sri Lanka.

Higgs, D. J., Morris, V. C. and Levander, O. A. (1972). Effect of cooking on selenium content of foods. Journal of Agricultural and Food Chemistry 20:678-680.
Mahagama, S.H.S. (2009). Selenium uptake by rice consumed by Sri Lankans. M.Sc. Dissertation. University of Kelaniya, Sri Lanka.

Neve, J. (1996). Selenium as a risk factor for cardiovascular diseases. Journal of Cardiovascular Risk 3:42-47.

Patrick, L. N. D. (2004). Selenium Biochemistry and Cancer: A Review of the Literature. Alternative Medicine Review 9(3):239-58.

Prasanna, E. G. J. (2014). Selenium Content in Rice, Cereals and Legumes Consumed by Sri Lankans, M.Sc. Dissertation. University of Kelaniya, Sri Lanka.

Sunde, R. A., Bowman, B.A. and Russell, R.M. (2006). Present Knowledge in Nutrition. Washington, D. C: ILSI Press 9: 480-497.

Dumont, E., Vanhaecke, F. andCornelis, R. (2006) Selenium speciation from food source to metabolites: A critical review. Analytical and Bioanalytical Chemistry 385:1304-1323. 
